\title{
Evaluation of the Implementation of University Social Responsibility in Morocco
}

\author{
Samira Mili, Abdelrhani Bouayad, Abdelali Lahrech
}

\begin{abstract}
Moroccan society is going through a series of transformations in its relations between institutions and the community; in this context, the university, starting from its university mission centered on training and investigation for the development of knowledge, promotes a major involvement concerning the needs of society, known as university social responsibility (USR). Indeed, lately we often approach the theme of "social responsibility" as an ethical dimension that each organization or institution should adopt, integrate and promote in its daily activity. The business world has obviously welcomed and developed the idea for a long time, however thinking about social responsibility has only just begun in universities, especially those in Morocco. This article aims to examine the current situation of the integration of USR practices within Cadi Ayyad University ranked first according to World University Rankings of 2019 and based on indicators developed by the model of Pacto Global Red Colombia of 2018 The results obtained demonstrate that despite the efforts made in this direction, the Moroccan University is in an embryonic stage compared to European universities.
\end{abstract}

Keywords: Corporate Social Responsibility, University Social Responsibility, Sustainability, Indicators, Stakeholders, environment.

\section{INTRODUCTION}

\section{C} urrently, corporate social responsibility has been found to have a significant impact on the fabric of business. Indeed, companies have as main objective the realization of profit, so that, not to harm their image and their social reputation, they must manage and inform that the achievement of this main objective does not generate negative externalities for citizens in particular and stakeholders in general [1]. However, the same did not happen in the university environment, where thinking about social responsibility is neglected or even absent, especially in the context of Moroccan universities. The management of organizations cannot be dissociated from their impact on the social environment or the context in which they operate. Thus, we are talking about its relevance and the different mechanisms used to improve its quality, improve management and report to society. In addition, meeting the needs of the inhabitants of a local or regional territory in terms of social life and culture, this is now one of the missions of a socially responsible university.

Revised Manuscript Received on March 13, 2020.

* Correspondence Author

Samira Mili*, Assistant Professor of Higher Education, Polydisciplinary Faculty of Errachidia, Moulay Ismail University - Meknes Morocco. E-mail:s.mili@umi.ac.ma

Abdelrhani Bouayad, Professor of Higher Education and Dean of the Faculty of Law, Economics and Social Sciences, Moulay Ismail University Meknes - Morocco. E-mail: doyen@fsjes.umi.ac.ma

Abdelali Lahrech, Professor of Higher Education, Faculty of Law, Economics and Social Sciences, Moulay Ismail University - Meknes Morocco. E-mail:lahrech_fac@yahoo.fr

(C) The Authors. Published by Blue Eyes Intelligence Engineering and Sciences Publication (BEIESP). This is an open access article under the CC BY-NC-ND license (http://creativecommons.org/licenses/by-nc-nd/4.0/)
Given the importance of integrated university education and social commitment in professional practice, since the beginning of the 21st century, the role of the university in contributing to sustainable development is reflected in what we called "university social responsibility". Therefore, the challenge of higher education institutions aims to design and apply a model that responds to the different dimensions of social responsibility, which integrates training, research, management of social knowledge in a socially responsible campus

\section{LITERATURE REVIEW}

The themes that are in fashion today are corporate social responsibility and university responsibility. There is currently no single dominant academic model of Social Responsibility. One reason is the very nature of this concept which is fluid and elastic. Behind each word that constitutes "social responsibility" hide several debates and different conflicts, starting with its definition until the modalities of its application. In other words, it is a broad and loose concept that should not be seen as an ad hoc strategy, but as a long-term process. The concept of social responsibility defines new rules - economic, social, and ecological - the application of which allows better coexistence between all actors in society.

\section{A. Corporate social responsibility}

The main function of businesses is economic in nature, but the main objective of the business is social, because the business cannot be sustained without interaction with consumers, customers and those around them in general. Indeed, prosperity is unthinkable amidst the deterioration that hits everything, that is, every organization cannot have prosperity if the environment around it does not thrive. Likewise, the organization of companies must necessarily take into account its internal and external stakeholders, experimenting with social responsibility practices with all its stakeholders, in order to survive in a sustainable manner over time.

Currently companies are devoting significant resources to various social initiatives, ranging from community outreach and environmental protection to socially responsible business practices [2]. To this end, several organizations and institutions have been created and have defined standards, strategies and guidelines regarding the criteria that organizations must meet, in relation to social responsibility and accountability to stakeholders (customers, shareholders, workers, suppliers, investors or other interest groups involved).

\section{Published By:}

Blue Eyes Intelligence Engineering

\& Sciences Publication

DOI: 10.35940/ijmh.G0685.034720

Journal Website: www.ijmh.org
(C) Copyriaht: All rights reserved.

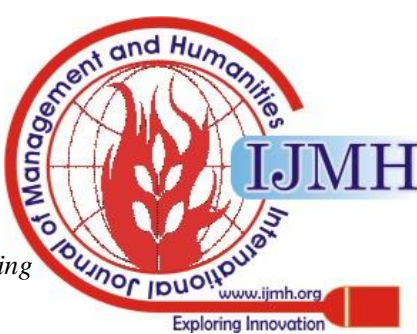


The business sector and the education sector in particular have changed, becoming aware of their role in sustainable development and based on the need to control the impact of their activities on the environment in which they operate. Corporate social responsibility (CSR) can be understood as a set of actions carried out by institutions to prevent, mitigate and compensate for the impacts generated by their activities, by promoting sustainable development where they operate.

Can we define the concept of "corporate social responsibility"? Without doubt this question is the one most often asked by all the actors having a direct or indirect link with the concept of CSR. The answer to this question is not final. Indeed, many definitions circulate around the concept "organization" without being neither harmonized nor standardized, and therefore do not always make unanimity within the researchers, but we can essentially retain the definitions of the following table:

Table 2.1. Definitions of corporate social responsibility

\begin{tabular}{|c|c|}
\hline Authors & Definitions \\
\hline $\begin{array}{l}\text { Bateman and } \\
\text { Snell } \\
(2005: 147)[3]\end{array}$ & $\begin{array}{l}\text { the socially responsible company maximizes } \\
\text { the positive effects on society and minimizes } \\
\text { its negative effects }\end{array}$ \\
\hline $\begin{array}{c}\text { Bowen (1953: } \\
\text { 6) [4] }\end{array}$ & $\begin{array}{l}\text { It refers to the obligations of businessmen to } \\
\text { pursue those policies, to make those } \\
\text { decisions, or to follow those lines of action } \\
\text { which are desirable in terms of the objectives } \\
\text { and values of our society }\end{array}$ \\
\hline $\begin{array}{l}\text { (European } \\
\text { Commission, } \\
\text { 2001) [5] } \\
\end{array}$ & $\begin{array}{l}\text { a concept whereby companies decide } \\
\text { voluntarily to contribute to a better society } \\
\text { and a cleaner environment }\end{array}$ \\
\hline $\begin{array}{l}\text { ISO 26000 } \\
(2010: 4)[6]\end{array}$ & $\begin{array}{l}\text { an organization's responsibility for the } \\
\text { impacts of its decisions and activities on } \\
\text { society and the environment, through } \\
\text { transparent and ethical behavior that: } \\
\text { - contributes to Sustainable Development, } \\
\text { including health and the welfare of society; } \\
\text { - takes into account the expectations of } \\
\text { stakeholders; } \\
\text { - is in compliance with applicable law and } \\
\text { consistent with international norms of } \\
\text { behavior; } \\
\text { - and is integrated throughout the } \\
\text { organization and implemented in its relations. }\end{array}$ \\
\hline $\begin{array}{c}\text { WBCSD(1999) } \\
\text { [7] }\end{array}$ & $\begin{array}{l}\text { the continuing commitment by business to } \\
\text { behave ethically and contribute to economic } \\
\text { development while improving the quality of } \\
\text { life of the workforce and their families as well } \\
\text { as of the local community and society at large }\end{array}$ \\
\hline
\end{tabular}

\section{B. The social responsibility of universities}

In its World Declaration on Higher Education on October 9, 1998, UNESCO states that "higher education and research are now essential components of the cultural, socio-economic and ecologically viable development of individuals, communities and nations ". The university is therefore no longer perceived only as an organization consuming resources, but, like business, as an organization creating social wealth. Like the company that had to overcome the philanthropic approach of social investment (as an additional expense) to fit into a new paradigm of that of Social Responsibility, the University should go beyond its central function of training students and producing knowledge, in order to assume the real requirement of social responsibility of universities. Higher education institutions around the world strive to implement and develop assessment systems, with the aim of ensuring the quality of higher education systems. In other words, a system that can integrate environmental management (internal and external), and design and execute actions in social and community projects for the benefit of sustainable development.

The social responsibility of universities can be interpreted as the conscience of the university, which directs its actions towards a categorical and necessary contribution in society, by responding to global and fundamental problems which arise in the current environment where the university is inserted.

The incorporation and implementation within the universities of the USR, becomes important because of the role that these institutions play as entities generating new knowledge and professionals who must be able to drive social, political and that society demands in the quest for sustainable human development.

Despite the importance of the theme of social responsibility of University, there is currently no definition of consent between the different authors, this is due first to the transversely of the concept and also to the novelty of its practices, because the conceptual definition of the term is not only more diversified than the term CSR, but it is also less developed than this one. However, we will discuss some definitions that have been presented recently. Vallaeys presents this definition "A policy of ethical quality in the activities of the university community (students, lecturers, administrative staff), through responsible management of the educational, cognitive, labor and environmental impact of the university, in a participative dialogue with society to promote sustainable human development" [8]. Meanwhile [9] defines the USR as: "The obligations of university managers to promote institutional policies to make decisions or to follow lines of action that are desirable in terms of the objectives and values of society" [9]. For the [10] "A university is socially responsible "for the prospective and transformative capacity it has as a social organization, by disseminating and implementing a set of principles and values through the intelligent management of impacts: organizational, environmental, educational, cognitive and social, produced through of its key processes: management, teaching, research and extension, through quality ethical policy, in participatory dialogue with society with whom it seeks together, a human and sustainable development and which specifies the ethical demand for justice and social equity"

The different definitions above have in common the evaluation of the impacts generated by the performance of universities which, through a certain number of indicators, can be measured and evaluated to know whether or not they comply with the objectives set.

Responsible practices that add value to the brand and the profitability of the entity are both accredited to its employees, suppliers, customers, investors, etc., "as an organization willingly committed to socially responsible management responsible within the framework of their organizational culture and their commercial strategy " [11]. These instruments become indicators when they measure the achievement of the objectives of projects or programs.

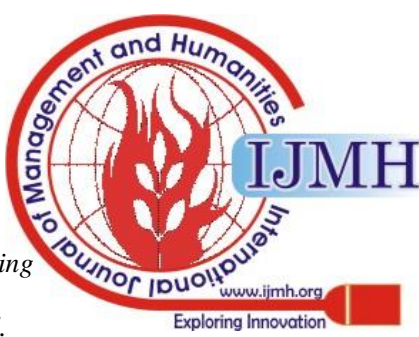


The implementation of a University Social Responsibility Management System implies a clear commitment to the interest groups of the university, through continuous improvement in USR practices, in all its dimensions, training and research, management organizational, and the university extension as well as the awareness of all its members.

\section{METHODOLOGY}

Methodological approach can be either qualitative or quantitative. This research consists of descriptive qualitative, a method that has been used in social sciences and humanities, this method of research is particularly appropriate when the factors observed are subjective, so difficult to measure. This is particularly the case because the social and environmental aspects included university social responsibility indicators in our case study which is Cadi Ayyad University, not always easy to calculate.

Qualitative research is a generic term that covers a variety of methods that are used in many disciplines [12]. It is multidimensional and is used to study phenomena in their natural setting with the use of interviews, analysis of archives, observations and surveys and attempting to interpret phenomena in terms of meaning provided by actors [12] \& [13]. It describes and explains the modes of relationships and data in the form of words and not necessarily in the form of figures, which makes it a more subjective approach compared to quantitative studies. It allows the researcher to establish themes, models, and categories of data based on the researcher's understanding and interpretation [14]. Qualitative research offers a holistic and holistic view, leading to an understanding of phenomena, and is therefore suitable for the construction of inductive theories [15]. In this article, we will follow the current of descriptive qualitative research based on the case study.

Yin defines the case study research method as an empirical investigation that studies a contemporary phenomenon in its real context; when the boundaries between the phenomenon and the context are not clearly evident; and in which multiple sources of evidence are used; and benefits from previous theoretical developments for data collection and analysis. This is particularly the case with our universities, because the collection of data is based on the review of documents (reports, reports, articles, etc.) of the universities that make our case study. Yin argue that, the case study is appropriate when asking a "How" or "Why" question about a contemporary set of events, in which the researcher has little or no control is our case, because the problem is: how can you measure the university social responsibility? David [16] identifies four types of cases: illustrative, typical, test, unpublished or exemplary. Our research is perfectly suited to the type of test, because the housing is selected because it allows you to test theories formulated previously. To this end, in this article we plan to apply a checklist of university social responsibility practices based on a number of indicators.

In this article, we will expose one Moroccan university. The choice is not made with the hasar but one followed the classification of World University Rankings of 2019 of the Moroccan universities, and according to which the University Cadi Ayaad is in the first rank, followed by the University Mohammed V, then the Sidi Mohammed Ben Abdellah University and finally Hassan II University in fourth position. The choice of Cadi Ayaad university is also explained by the information available on its web page in terms of USR.

The method chosen is that developed by Pacto Mondial Red Colombia in 2018, by a number of experts, this model represents virtues in particular it is a system that first allows the definition of management parameters and objectives in terms of social responsibility inside the educational establishment, then the possibility of choosing the level of the report to be developed according to the advances in these practices and institutional interests, and finally the compatibility of these indicators with those developed by the management systems the most famous.

This model follows a very precise logic, articulated in 5 steps: (1) define scope (2) establish level (3) collect information (4) prepare report (5) submit report. As mentioned, the objective of this article is to determine the current situation of the chosen University in relation to the performance of social responsibility practices, for this we will go directly to the second step. Besides, the Cadi Ayyad University has set up a USR system, and therefore the definition of the objective, and the determination of its stakeholders is essential, for this we deemed useless to go through the first step, because this is not an establishment of a USR system, but otherwise an assessment of the current state.

\section{RESULTS}

As we have just mentioned in terms of research methodology, we will constitute an array of indicators developed by theoretical and empirical work [17] \& [18] Moreover, according to [17] good practices in terms of social responsibility must be integrated into the following functions: (1) academic and pedagogical training, (2) research and dissemination, (3) management of the organization and (4) social participation, through the creation of communication and participation channels to meet the demands of its interest groups. [19] Demonstrates that "The initiatives that socially responsible universities can undertake to contribute to sustainable human development encompass a wide range of proposals that are based on four fundamental areas of university work that constitute the pillars of the USR: training, research, extension, and socially responsible university management.

And finally the expects of Pacto Global Red Colombia (2018) indicate that the indicator system is composed of five main elements, which constitute the main functions of higher education establishments, these elements are: teaching, research, leadership and strategy, operation management and social extension or projection. Each of these five functions is made up of aspects that are sufficiently necessary to be able to apply institutional management that meets the objectives of sustainable development by 2030 .

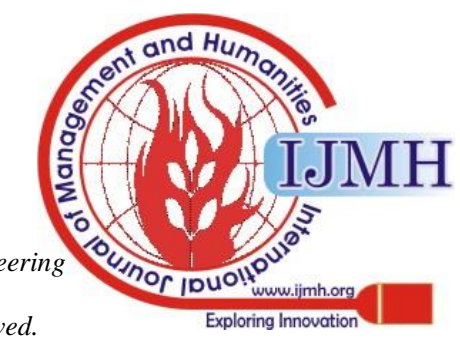


Table 4.1. Definition of the five areas of Pacto Global Red Colombia (2018)

\begin{tabular}{|c|c|}
\hline Area & Definition \\
\hline Leadership and Strategy & $\begin{array}{l}\text { This component refers to the } \\
\text { strategic direction and the existence } \\
\text { of specialized control mechanisms } \\
\text { for the evaluation of the promotion } \\
\text { of social aspects in the institution }\end{array}$ \\
\hline Teaching & $\begin{array}{l}\text { This component refers to academic } \\
\text { content, thematic methodologies and } \\
\text { learning processes that promote } \\
\text { training for sustainability and foster } \\
\text { responsible leadership }\end{array}$ \\
\hline Research & $\begin{array}{l}\text { This component refers to the } \\
\text { evaluation of the existence of } \\
\text { guidelines and policies that promote } \\
\text { the acquisition of new knowledge } \\
\text { and its application for the solution of } \\
\text { social and sustainable problems in } \\
\text { the institution }\end{array}$ \\
\hline Extension or Social Projection & $\begin{array}{l}\text { This component defines the number } \\
\text { of initiatives and formal bases that } \\
\text { evaluate through social mechanisms } \\
\text { and policies social aspects and } \\
\text { sustainability }\end{array}$ \\
\hline $\begin{array}{l}\text { Administration of the } \\
\text { Operation }\end{array}$ & $\begin{array}{l}\text { This component studies the impact } \\
\text { generated by the institution through } \\
\text { its administrative and operational } \\
\text { processes to its stakeholders and the } \\
\text { environment }\end{array}$ \\
\hline
\end{tabular}

Pacto Global Red Colombia (2018: 9) [18]

To report the performance of the components or areas, these are divided into General Aspects, these in turn into Sub Aspects and finally each Sub Aspect is divided into Indicators.

- General Aspects: they are defined as the essential and significant issues with which each area or substantive function must take into account when assessing its commitment to sustainability.

- General Aspects: they are understood as the group of criteria that make up each of the themes of university sustainability (general aspects) and that of course are likely to be evaluated through indicators.

- Indicators: they are punctually the set of data, whether qualitative and / or quantitative, with which the performance of the relevant sustainability criteria is evaluated in an objective and traceable manner.

The Pacto Global Red Colombia 2018 report sets out five steps (define scope, establish level, collect information, prepare report, present report) to be followed by establishments as they become involved in social responsibility practices, which demonstrates the flexibility of the model. It begins with the Basic level, then standard, then intermediate until reaching the most advanced level. In our case, given that these practices at the level of Moroccan universities are still recent, we are going to place ourselves at the basic level. The report at this level claims that the academic institution In addition to providing the basic data, establish the formality (policies, mechanisms, etc.) with which sustainability efforts are supported.

Table 4.2. Evaluation of the Fulfillment of social responsibility practices according to the basic level

\begin{tabular}{|c|l|l|}
\hline Area & Code & \multicolumn{1}{c|}{ Description } \\
\hline Leadership & L23 & $\begin{array}{l}\text { Mention the year of commencement of } \\
\text { sustainability or social responsibility } \\
\text { reporting or reporting activities. } \\
\text { Mention the methodology used (own, } \\
\text { GRI, IR, COE). }\end{array}$ \\
\hline
\end{tabular}

\begin{tabular}{|c|c|c|}
\hline & L27 & $\begin{array}{l}\text { Mention whether in the report or report } \\
\text { on sustainability and / or social } \\
\text { responsibility the performance of the } \\
\text { commitments with the Social } \\
\text { Development Goals - publication period }\end{array}$ \\
\hline Teaching & $\begin{array}{l}\text { T5 } \\
\text { T8 } \\
\text { T10 } \\
\text { T15 } \\
\text { T19 } \\
\text { T35 }\end{array}$ & $\begin{array}{l}\text { Number of academic programs by type } \\
\text { (undergraduate, specialization, masters, } \\
\text { doctorate) with seniority. } \\
\text { Number of actions, events or campaigns } \\
\text { per year per program / duration. } \\
\text { Number of subjects and / or associated } \\
\text { subjects per program / total subjects per } \\
\text { program. } \\
\text { Number of actions, events or campaigns } \\
\text { per year per program } \\
\text { Number of actions, events or campaigns } \\
\text { per year per program. } \\
\text { Number of actions, events or campaigns } \\
\text { per year } \\
\text { Mention the Sustainable Development } \\
\text { Goals related to curricular meshes or } \\
\text { training activities by academic program }\end{array}$ \\
\hline Research & $\begin{array}{l}\text { R1 } \\
\text { R6 } \\
\text { R7 } \\
\text { R9 }\end{array}$ & $\begin{array}{l}\text { Number of lines, groups or research } \\
\text { projects with status and seniority } \\
\text { Number of empirical studies / total } \\
\text { research. } \\
\text { Number of versions offered at no cost of } \\
\text { research / total research. } \\
\text { Number of investigations carried out } \\
\text { under sustainability guidelines or social } \\
\text { responsibility / total investigations } \\
\text { made. } \\
\text { Total number of academic products in } \\
\text { Social Responsibility and Sustainability } \\
\text { / total academic products. } \\
\text { Mention the Sustainable Development } \\
\text { Goals prioritized in research activities }\end{array}$ \\
\hline Extension & $\begin{array}{l}\text { E21 } \\
\text { E23 }\end{array}$ & $\begin{array}{l}\text { Number of initiatives, projects and / or } \\
\text { programs per category per year and } \\
\text { seniority } \\
\text { Number of initiatives, projects, } \\
\text { programs with student participation / } \\
\text { total initiatives, projects and / or } \\
\text { programs made. } \\
\text { Number of initiatives, projects and / or } \\
\text { programs with teacher participation / } \\
\text { total initiatives, projects and / or } \\
\text { programs } \\
\text { Performed /\% of the university budget } \\
\text { allocated to these } \\
\text { Number of alliances, agreements or } \\
\text { agreements with institutions / actions } \\
\text { carried out. } \\
\text { Number of initiatives, projects and / or } \\
\text { programs promoting } \\
\text { Responsibility and / or Sustainability / } \\
\text { total initiatives, projects and / or } \\
\text { programs carried out } \\
\text { Mention the Sustainable Development } \\
\text { Goals prioritized in extension or social } \\
\text { projection activities }\end{array}$ \\
\hline Administration & $\begin{array}{l}\text { A2 } \\
\text { A12 }\end{array}$ & $\begin{array}{l}\text { Total number of employees broken } \\
\text { down by gender, seniority and type of } \\
\text { contract and salary information. } \\
\text { Total number of new hires x type of } \\
\text { contract. } \\
\text { Number of hours of training by workers } \\
\text { by category or rank and gender }\end{array}$ \\
\hline
\end{tabular}

Pacto Mondial Red Colombia (2018: 17) [18]

We will fill the table above by just taking the fields and the codes, the information used comes from the web page of Cadi Ayyad University, in the section called social responsibility of the University simplify the evaluation.

Published By:

Blue Eyes Intelligence Engineering

\& Sciences Publication

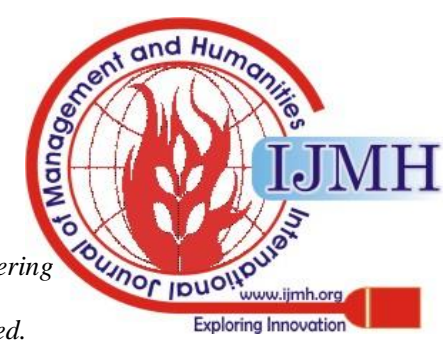


Table 4.3. Application on Cadi Ayyad University

\begin{tabular}{|c|c|c|}
\hline Area & Code & Université Cadi Ayyad \\
\hline Leadership & $\begin{array}{l}\text { L23 } \\
\text { L24 } \\
\text { L27 }\end{array}$ & $\begin{array}{l}2017 \\
\text { the axes are compatible with the GRI } \\
\text { but the social responsibility report is } \\
\text { not available. } \\
\text { Yes / 2013-2015; 2017-2019 }\end{array}$ \\
\hline Teaching & $\begin{array}{l}\text { T1 } \\
\text { /T8 }\end{array}$ & $\begin{array}{l}\text { Several programs are planned, } \\
\text { including the masters: Master in } \\
\text { Social Economy and Sustainable } \\
\text { Development, Master in Strategy } \\
\text { and Human Resource Management, } \\
\text { Specialized Master in } \\
\text { Environmental Economics (EE), } \\
\text { Master in International Economy, } \\
\text { Governance and Development, } \\
\text { Master in Law Man and Public } \\
\text { Liberties. The list is not exhaustive; } \\
\text { there are still professional licenses } \\
\text { and masters in sustainable } \\
\text { development subjects. } \\
\text { For example, the Master "Social } \\
\text { economy and sustainable } \\
\text { development is part of the current } \\
\text { changes in development policies } \\
\text { seeking to reconcile economic } \\
\text { efficiency with social equity and the } \\
\text { preservation of natural resources. In } \\
\text { this perspective, we are witnessing a } \\
\text { renewed interest in the social and } \\
\text { solidarity economy dedicated to } \\
\text { activities meeting needs not covered } \\
\text { either by the market or by the State }\end{array}$ \\
\hline Research & $\begin{array}{l}\text { R9/ } \\
\text { R13/ } \\
\text { R17 }\end{array}$ & $\begin{array}{l}\text { in this section there is a fairly large } \\
\text { and fairly rich research structure, } \\
\text { some research teams are cited: } \\
\text { Research Group on Human Rights } \\
\text { and Transition to Democracy, } \\
\text { Research Group in Innovation, } \\
\text { Responsibilities and Sustainable } \\
\text { Development, Research Group in } \\
\text { Social and Solidarity Economy, } \\
\text { Human Ecology Laboratory, } \\
\text { Biotechnology Laboratory, } \\
\text { Protection and Development of } \\
\text { Plant Resources... } \\
\text { Here we will cite the projects that we } \\
\text { found in the USR section: } \\
\text { Sustainable Development project of } \\
\text { a culture of health and safety at } \\
\text { work, Project of Valorisation of } \\
\text { liquid effluents from the olive } \\
\text { industry for a sustainable olive } \\
\text { cultivation respectful } \\
\text { environment, project to develop } \\
\text { innovative strategies for improving } \\
\text { water quality drinking in Safi and } \\
\text { regions. ONLY cited } 3 \text { projects but } \\
\text { there are } 34 \text { projects involved in } \\
\text { economic, social and environmental } \\
\text { development torion } \\
\text { Mention investigations carried out } \\
\text { under sustainability guidelines or } \\
\text { social responsibility / total } \\
\text { investigations made. }\end{array}$ \\
\hline Extension & $\begin{array}{l}\text { E11 } \\
\text { E12 }\end{array}$ & $\begin{array}{l}\text { Mention initiatives, projects and / or } \\
\text { programs per category per year and } \\
\text { seniority } \\
\text { Blood donation campaign with the } \\
\text { participation of the whole } \\
\text { University; } \\
\text { the projects cited above } \\
\text { (R9/R13/R17) are in favour of the }\end{array}$ \\
\hline
\end{tabular}

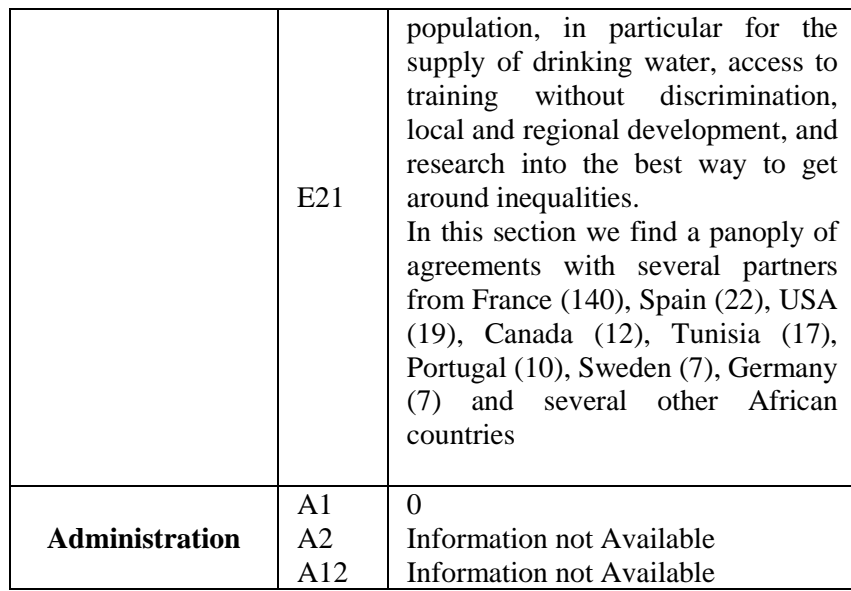

Own elaboration from Pacto Mondial Red Colombia (2018)

\section{DISCUSSION OF THE RESULTS}

As shown in table (4.2.), The Cadi Ayyad University has done a colossal job in implementing social responsibility practices, integrating them into all of these formative, administrative, teaching and also investigation. Indeed, the projects initiated by the university's research laboratories all include environmental, social and governance concerns. The table does not make it possible to highlight either the set of practices undertaken by the University nor the actions and activities nor the set of its projects, or even the conventions and alliances, since we treated to dissect only the most important to test the application of this model.

It is a simple model, flexible and easy to set up by any establishment since it sets up tables with indicators (which can change according to the need and the context of each establishment) and each table corresponds to a well-defined level from the basic level, passing through the standard and the intermediate and arriving at the advanced level, and each time the indicators evolve and the integration of USR practices becomes more important. We recall, that this model does not only allow the assessment of the current state of social responsibility, but also it is a guide for those who wish to integrate USR practices for the first time, since this model presents five stages allowing to pass from an embryonic phase which is the determination of the objective in terms of social responsibility to a phase of disclosure for the benefit of the stakeholders.

\section{CONCLUSION}

If in European universities the theme of integration of university social responsibility practices is a priority and a requirement, within Moroccan universities, this is far from being achieved. Indeed, the Moroccan university has operated since its creation in ignorance of people's expectations and environmental requirements. Although some student activities (sports, cultural, associative) may appear to be USR practices, the Moroccan university is called to report to stakeholders, How? Through, the disclosure of its activities in the form of a university social responsibility brief on its web page.

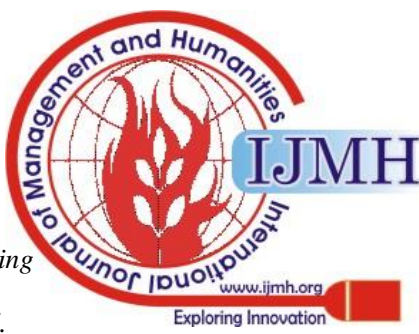


Many are the benefits of implementing USR practices, according to [17] The USR helps the university to articulate its teaching, research and extension functions in an ethical and responsible management. Likewise, it allows achieving coherence between the declarations of intentions (mission, vision and values) and the daily actions of the University.

According to the same author [17], the implementation of the USR allows to take advantage of an institutional dynamic towards innovation, that is to say that the university becomes an intelligent, transparent and democratic organization, and that applies continuous improvement processes, facilitating creative initiatives in academic and management fields. And finally, it allows the rationalization of university management, so that the university improves the performance of its processes in different fields (care of the environment, motivation of workers, improvement of academic performance, and creation of social value).

\section{REFERENCES}

1. Larrán Jorge, M., De la Cuesta, M., Fernández, A., Muñoz, M. J., López, A., Moneva, J. M.,\& Andrades Peña, J. (2012). Análisis del nivel de implantación de Políticas de Responsabilidad Social en las Universidades Españolas. In Conferencia de Consejos Sociales de las Universidades Públicas Españolas. Fundación Carolina.

2. Du S, Bhattacharya C, Sen S (2010). Maximizing business returns to corporate social responsibility (CSR): The role of CSR. Int. J. Manag. Rev. 12: 8-19.

3. Bateman, T. S., \& Snell, S. A. (2005). Administración: Un nuevo panorama competitive.

4. Bowen, HR 1953, Social responsibilities of the businessman, New York: Harper \& Row.

5. European Commission. Directorate-General for Employment and Social Affairs, Industrial Relations and Industrial Change, Unit EMPL/D.1: 2001, Promoting a European Framework for Corporate Social Responsibility, Green Paper (Office for Official Publication of the European Communities, Luxembourg), http://europa.eu.int/comm/employment_social/

soc-dial/csr/greenpaper_en.pdf (accessed December 15, 2006).

6. Hemphill, T. (2013). The ISO 26000 guidance on social responsibility international standard: What are the business governance implications?. Corporate Governance: The international journal of business in society.

7. WBCSD, 1999. Corporate Social Responsibility. World Business Council for Sustainable Development, Geneva.

8. Vallaeys, F. (2007): Responsabilidad social universitaria. Propuesta para una definición madura y eficiente, Instituto Tecnológico de Estudios Superiores de Monterrey, México.

9. Gaete Q., R. (2012): La responsabilidad social universitaria: una mirada a la relación de la universidad con la sociedad desde la perspectiva de las partes interesadas. Un Estudio de caso, Tesis Doctoral, Universidad de Valladolid.

10. Universidad Construye País (2004). Observando la Responsabilidad Social Universitaria. Documento de trabajo versión actualizada. Edición proyecto Universidad construye país. Santiago de Chile

11. Yfarraguerri L., (2014) Necesidad de Indicadores de Medición de la Responsabilidad Social en las Universidades. Daena Internatinal Journal of Good Conscience. 9(1) 142-157. ISSN 1870-557X.

12. E. G. Guba, \& Y. S. Lincoln, "Competing paradigms in qualitative research". Handbook of qualitative research, 1994, 2(163-194), 105.

13. N. K. Denzin, \& Y. S. Lincoln, "Introduction: The discipline and practice of qualitative research", Sage Publications, second edition, 2005.

14. M. B., Miles, \& A. M. Huberman, "Qualitative data analysis: An expanded sourcebook", sage, 1994.

15. C. Perry, "Processes of a case study methodology for postgraduate research in marketing", European journal of marketing, 1998, 32(9/10), pp. 785-802.

16. A. David. Des rapports entre généralisation et actionnabilité: le statut des connaissances dans les études de cas. In 6ème Congrès Européen de Science des Systèmes. Paris, 2005, pp. 1-17.

17. González Alcántara, Ó.; Fontaneda González, I.; Camino López, M.A.; Revilla Gistaín, A. (2015): La responsabilidad social en las universidades españolas 2014/15, IAES, Serie Investigaciones.
18. Pacto Mondial Red Colombia 2018: Sistema de indicadores de responsabilidad social universitaria informe de progreso - PRME, ISBN - 978-958-56842-0-1 Bogotá D.C. Colombia, Septiembre 2018

19. T.B. Salinas Lopez. La responsabilidad social universitaria. Un estudio comparativo de las prácticas de las universidades españolas y de su divulgación, Tesis Doctoral, Universidad de Vigo (España), 2017.

\section{AUTHORS PROFILE}

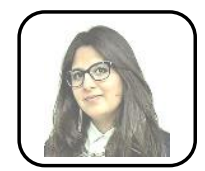

Samira MILI, Assistant Professor of Higher Education, Polydisciplinary Faculty of Errachidia, Moulay Ismail University - Meknes - Morocco.s.mili@umi.ac.ma

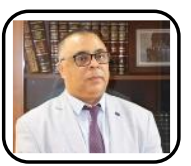

Abdelrhani BOUAYAD, Professor of Higher Education and Dean of the Faculty of Law, Economics and Social Sciences, Moulay Ismail University - Meknes - Morocco.doyen@fsjes.umi.ac.ma

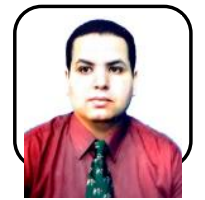

Abdelali LAHRECH, Professor of Higher Education, Faculty of Law, Economics and Social Sciences, Moulay Ismail University - Meknes - Morocco. lahrech_fac@yahoo.fr

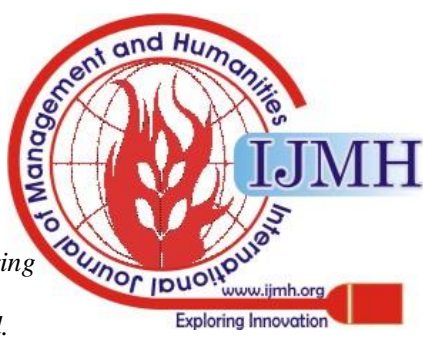

